\section{RUSSIAN SCIENTIFIC WORKS}

THREE volumes of the Bulletin of the Academy of Sciences, containing the proceedings of the physicomathematical section, have been received recently. In vol. xxii. Mr. Wyragevitch describes certain Actinozoa of the Black Sea in the neighbourhood of Balaclava, and $\mathrm{Mr}$. A. Borissiak contributes notes on the Black Sea plankton. Mr. K. N. Davidoff's article on the islands of the IndoAustralian archipelago deserves mention. The confusion of European and Malay races in Amboina has produced a curious type, and the Malay tongue has absorbed, it is shown, Dutch and Portuguese words. The barbarous custom of wooing with the head of an enemy still prevails. The Solifugæ of Persia are discussed by Mr. A. Birula. In vol. xxiii. Mr. V. Bianchi writes on Passeriformes and Palæarctic larks, basing his remarks on studies in the museums of London, Tring, and Paris. Mr. N. Donitch contributes observations of the annular solar eclipse in March, 1904, made at Cambogia, and of the total solar eclipse in August, 1905. The latter was observed from Alcala and Assouan. Notes on inundations at St. Petersburg are contributed by Mr. S. Griboyedoff, and studies of rainfall in that capital, with diagrams and tables, are given by Mr. E. Rosenthal. Vol. xxiv. contains the results of lengthy investigations, by Mr. A. Bielopolsky, of the radial velocity of the variable star Algol, and another astronomical paper, by Mme. Zhiloff, on the orbit of the minor planet Doris (48). A new species of pheasant from the mountain regions of western China is described by Mr. V. Bianchi. Details of balloon experiments at the aërodynamic institute at Kutshino are furnished by $\mathrm{Mr}$. V. Kuznetsoff. From fossils collected by the Polar expedition of the late Baron Toll in 1900-3, Mme. M. Pavloff is able to draw deductions as to the changes of climate in east Siberia since the Tertiary period. Several papers on aërial mechanics are contributed by Mr. D. P. Riabushinsky. Mr. M. Golenkin writes on a botanical visit to Java, and the report of the geological museum of Peter the Great cuncludes the volume.

In series vi., part $i$., of the Bulletin of the Imperial Academy of Sciences, Prince B. Galitzin describes the seismic station at. Pulkovo. Mr. P. Vannari writes on the duration of sunshine in Russia. Part ii. opens with suggestions, by Mr. M. A. Nikatshev, for the establishment of a commission to arrange atmospheric observations in different parts of Russia. A memoir of Prof. D. I. Mendeléeff appears in part iii. Memoirs of the geologist N. A. Sokoloff, the chemist H. Moissan, the German meteorologist W. von Bezold, and Signor G. I. Ascoli, philologist, appear in part iv. Among short abstracts of papers is one by Mr. A. Kuljabko on the application of artificial circulation to heads of fishes after cutting them off, and one by Mr. V. Bianchi on Muscicapidæ. In a note on the temperature of lakes, Mr. V. B. Shostakovitch confirms the opinion of Middendorf that a mass of water heated in summer will retain this heat for a long time in spite of heavy frost and snow on the surface. Part v. contains memoirs of the geologist Bertrand and the chemist Berthelot. Mr. A. S. Skorikoff has made elaborate investigations of the plankton of the Taurida pond, St. Petersburg. Mr. S. P. Popoff has studied crystalline phosphates from the shores of the Gulf of Kertch. Prince B. Galitzin writes in part vi. on lines in the spectrum of mercury vapour. Mr. N. Korostelev reports on actinometrical observations at Tashkent in February of last vear. Of geological interest are the papers by Mr. A. Fersmann on stolpenite from the Rhone and pyrargyrite from the Pervoblagodatsk ore in the Urals. In part vii. Mr. V. Bianchi describes forms of Pyrrhospiza.

Papers by Mr. A. Karpinsky on the results of soundings in the Pripet basin, and by Mr. A. Fersmann on the mineralogy of the Simferopol district, will be found in part ix. In part x. Mr. F. N. Tshernisheff writes on the discovery of Upper Trias in the northern Caucasus, based on the researches of Mr. V. I. Vorobieff. Mr. Y. S Edelstein writes on the discovery of Upper Silurian layers in the neighbourhood of Samarkand. The longest paper is that of Mr. V. I. Vernadsky, on striation in crystalline surfaces, with mathematical illustrations. In No. II brief notices are given of papers on different investigations, which are to appear in extenso either in the Annals of the Zoological Museum or the Transactions of the Academy. One of the most interesting of these is the abstract of $\mathrm{Mr}$. L. S. Berg's paper on the fish of the Amur basin, where the fish consist of a mixture of Palæarctic and tropical forms. Two articles are devoted to crystallography; $\mathrm{Mr}$. V. V. Karandeieff writes on rotatory power and symmetry, and Mr. V. I. Vernadsky discusses the physical theory of twin formation and crystalline groups. Some critical forms of Centaurea, L., are described by Mr. A. Petunnikoff. A controversial article, "In Defence of Natural Genera," written in English, is contributed by $\mathrm{Mr}$. V. Bianchi, who differs from Dr. E. Hartert over what he calls "genus lumping."

In No. I2 Mr. V. Lubimenko gives a paper on the influence of light on the absorption of organic substances by green plants. Investigations were directed to (i) has light any influence on the assimilation of organic combinations, where photorsynthesis is entirely absent? (ii) what is the influence of light of different intensities? (iii) is the influence of light dependent on the absorption of different wave-lengths? Experiments connected with light and the absorption of saccharose, glucose, and maltose are described, and $\mathrm{Mr}$. Lubimenko hints that further experiment will provide interesting results. $\mathrm{Mr}$. P. K. Kokovtsov's paper on some Central Asian tombstone inscriptions of Syrian-Christian character belongs to literary archæology. Astronomers will be interested in the calculations (in French) of the elements of Encke's comet, by Mr. Kamensky and Mdlle. E. Korolikov. There are short communications by $\mathrm{Mr}$. O. Backlund upon the rhombic pyroxene of a hypersthenic gneiss, and by $\mathrm{Mr}$. P. Stepanov on the Upper Silurian fauna of the Lake Balkhash district. Prof. G. D. Romanovsky studied the palæontological materials of Turkestan gathered by different investigators, and sedimentary formations belonging to all periods from the Silurian, with the exception of the Permian period, have been identified in that province.

Much research is recorded in vol. iii. of Mr. G. E. Grum-Grzhimailo's description of a journey in western China, round Kuku-nor, through Nan-shan, Bei-shan, and along eastern Tian-shan to Russia. There are handsome maps of Nan-shan, Bei-shan, and Tian-shan, showing the route of the expedition, twenty-five phototypes, and twentynine zincographs. The earlier chapters describe the route and adventures; the later chapters and appendices deal with natural history. 'The women of the Panaks (Kuku-nor Tanguts), who are in a position of humility, maintain an immemorial custom of veiling their faces in their plaited hair before strangers. There are two chapters on the ethnology of Amdo and the Kuku-nor region, the native names of localities being given with explanations and comparisons. One conclusion is that there is a strong white admixture among the Tibetans, who have a legend that their first king came from India. Butterflies (e.g. Agrotis xanthographa, F., and Pseudohadena pexa) approached the encampment when the temperature was surprisingly low. The Mongols and Tibetans consider the bear as king of beasts, and in the nature of a missing link between man and beast. It is thought that tales of "dumb, hairy savages" may sometimes be traced to inexperienced travellers who have seen bears. A rock was seen bearing an inscription in Mongolian and Tibetan, the Buddhist prayer "Hail, Pearl hidden in the Lotus," probably referring to nirvana, the translation and interpretation of which are a mystery. There are explanatory notes by Gabet and Waddell. Two legends with regard to the origin of kite-flying among the Chinese are recorded. When the expedition refused the offer of a convoy; the Chinese commander remarked, "Your men are a hundred times braver than our soldiers." A chapter is devoted to the climate of Tibet. Extensive study of the fauna shows that many examples of Siberian forms occur in Tian-shan, Han-su, and Pamir fauna, and our author traces the probable route of these forms by way of the Caucasus and Hindu-kush. As regards Lepidoptera, the interior regions of Tibet are a terra incognita. Several pages are occupied with the distribution and classification of Parnassius and Colias. The wanderings of the Old Believers, mentioned by Prjevalsky and Kozlow, are the subject of a separate chapter.

$$
\text { No. } 2017 \text {, vol. } 78[
$$


A rich and interesting ornithological collection of 1500 skins, twenty-two eggs, five nests, and three skeletons made by Mr. Kozlow, has been entrusted to the experienced hands of $\mathrm{Mr}$. V. Bianchi, and its description is contained in "Mongolia and Cham," vol. v., "Aves expeditionis Kozlowi." Eight new endemic forms were discovered. The name Cham or Kham relates broadly to the whole Alpine country of south-eastern Tibet, and in a narrower sense it refers to the area upon which agriculture is possible at a certain height. In the latter sense the boundaries of Cham are still uncertain. The volume opens with a physicogeographical sketch of the regions traversed by the expedition, passing to tables of distribution and analyses of the different species. The chief interest of the collection is that it was made in localities previously unvisited by European naturalists. Four plates of birds appear at the end, with a map indicating the routes of $\mathrm{Mr}$. Kozlow and his colleagues. The longitude is reckoned from Pulkova, $50^{\circ}-80^{\circ}$, the difference of longitude between Greenwich and Pulkova being $30^{\circ} 19^{\prime} 40^{\prime \prime} \cdot 10$. The classification of diatoms was entrusted to $\mathrm{Mr}$. K. S. Merezhkovsky, and Mr. N. A. Tatshaloff recorded the astronomica results of this important expedition, their work being contained in two shorter volumes.

\section{THE AMERICAN PHILOSOPHICAL SOCIETY.}

THE general meeting of the American Philosophical Society was held at Philadelphia on April 23-25. The opening session was on April 23, and morning and afternoon sessions were held on the following days, with an evening lecture by Prof. H. F. Osborn on April 24 at the hall of the Historical Society of Pennsylvania, which was followed by a reception to the visiting members and friends of the society. The sessions were largely attended. The meeting closed with a dinner at the Bellevue-Stratford on the evening of April 25.

Forty-two papers were presented, covering a wide range of subjects, but we are only able to find space for summaries of a few of them.

"Determination of Dominance in Mendelian Inheritance," Dr. C. B. Davenport. In studying heredity, where a single character is considered which one parent possesses and the other lacks, or a character that is contrasted in the parents, it is generally found that the offspring are alike, and like one parent only. From examples of poultry, of insects, of certain mammals, including man, and certain plants, in regard to inheritance that may be described as Mendelian, it is concluded that where a stronger determiner meets a weaker determiner in the germ, dominance is the result. When the character is present in one parent only we have the extreme case and typical Mendelian inheritance, but when the determiners are of nearly equal potency the Mendelian law is obscured.

"A Preliminary Report upon a Crystallographic Study of Hæmoglobins : a Contribution to the Specificity of Vital Substances in Different Vertebrates," Profs. E. T. Reichert and A. P. Brown. The primary object of this research was to determine whether or not corresponding albuminous substances are identical in different species. The results of the investigation, which has covered more than one hundred species of vertebrates, show:-(a) the crystals of oxyhæmoglobin obtained from any single genus are isomorphous, but unlike those obtained from other genera unless these. genera are closely related or in the same family: (b) specific differences in angle and habit are obtained between crystals obtained from species of the same genus, so that it is generally possible to re-organise the species by the crystals; (c) the occurrence of several types of crystals of oxyhæmoglobin in the same species; (d) indications are found in the crystal angles of a sirbstance in the molecule common to all hæmoglobins, no matter what the system of crystallisation. The application of this method of research to problems in zoological classification and in heredity was pointed out.

"The Effect of Certain Preservatives upon Metabolism," Dr. H. W. Wiley. Details were given of the work that Dr. Wiley is carrying on in the study of the effect upon the human organism of a number of preservatives commonly used in the preparation of foods, such as borax, boric acid, salicylic acid and salicylates, sulphurous acid, sulphites, benzoic acid and benzoates, formaldehyde, copper sulphate, and potassium nitrate Experiments with the first five of these preservatives show conclusively that their continued use, in quantities such as are used in food preservatives, hinders or prevents metabolism, and may seriously derange the functions of the organism. The other substances enumerated are still under investigation, but the results thus far obtained seem to indicate that they are equally injurious.

" Observations Regarding the Infliction of the Death Penalty by Electricity," Prof. E. A. Spitzka. This paper sets forth the history of "electrocution," the methods employed, and the phenomena observed in this mode of death, together with the post mortem findings, detailing the observations of the author, based upon thirty-one electrocutions at Sing Sing, Auburn, Dannemora, and Trenton prisons. Compared with other methods, " electrocution " is the most humane method of inflicting the death penalty, because of its efficiency, quickness, and painlessness, and it should be adopted in every State in the Union.

"A Comparison of the Albino Rat with Man in Respect to the Growth of the Brain and the Spinal Cord," Prof. H. H. Donaldson. A statistical study of the growth of the brain and the spinal cord in the white rat, in which the weight of the brain and of the spinal cord is recorded and compared with the body weight at various stages of the development of the animal. The results are plotted, and from these records logarithmic curves are drawn. When compared with the curves derived from the same data in the case of man, and plotted to a corresponding scale, a close similarity in the curves is noted.

"The Classification of the Cetacea," Dr. F. W. True The opinion is expressed that the Cetacea are not directly derived from Zeuglodonts, and that their origin is not at present known; also that the white whale and the narwhal should not be removed from the family Delphinidæ, and that the river dolphin, St $t$ nodelphis, should, for the present at least, be placed in that family,

"Results of the American Museum Exploration in the Fayûm Desert of Northern Egypt," Prof. H. F. Osborn. The camp of the American Museum Expedition was located to the west of Qasr el Sagra, near the bone quarries opened by Beadnell. Remains of Arsinoitherium, Palæomastodon, and Mœritherium were obtained from these quarries. A reconnaissance into the Zeuglodon valley, near Gar el Gehannem, was described. The restorations of Mœritherium and Palæomastodon, made by Mr. Charles $R$. Knight under the direction of Prof. Osborn, were exhibited. From northern Africa the elephant stock migrated south through Africa, north into Europe, and north-east and east through Asia into the Americas. From a comparison of the ancestral elephant Mœritherium with the Sirenian Eotherium, it is believed that the sea-cows and elephants are derived from the same stock.

"Additional Notes on the Santa Cruz Typotheria," Dr. W. J. Sinclair. A presentation of the general conclusions reached as a result of two years' study of the Typotheria from the Santa Cruz formation of Patagonia. They appear first in the Notostylops beds (uppermost Cretaceous or basal Eocene), and become extinct in the Pampean (Pleistocene). It is generally assumed that the rodents and conies are related to Typotheria, but this does not appear to be the case; the resemblances are probably due to convergence. The Toxodontia and the Typotheria probably had a common origin. The Typotheria do not lend much support to the idea of a former land connection with Africa, showing no relationship with the recently discovered Eocene mammals from the Fayum province of Egypt.

"Progress in the Demarcation of the Boundary between Alaska and Canada," Prof: O. H. Tittmann. Details are given of the methods employed in determining the Alaskan boundary. The length of the boundary is about twelve hundred miles, extending from the Arctic Ocean south along the I4Ist meridian to near Mt. St. Elias, and thence along the coast strip of south-eastern Alaska. In southeastern Alaska aluminium-bronze monuments are placed wherever it is practicable to do so, but, as most of the turning points in the line are inaccessible snow-clad peaks, they will be defined by triangulation connection with the

NO. 2OIz. VOL. $7^{8]}$ 